\title{
PENDIDIKAN ISLAM DALAM SURAH LUQMAN
}

\author{
Abdan Rahim \\ Dosen STIT Ibnu Rusyd Tanah Grogot, Kabupaten Paser Kalimantan \\ Timur \\ $\underline{\text { abdan628 gmail.com }}$
}

\begin{abstract}
Abstrak
Tujuan pendidikan Islam, tidaklah sekedar proses alih budaya atau ilmu pengetahuan (transfer of knowledge) tetapi juga proses alih nilai-nilai ajaran Islam (transfer of Islamic values). Tujuan pendidikan Islam pada hakikatnya menjadikan manusia yang bertaqwa, manusia yang dapat mencapai al-falah, serta kesuksesan hidup yang abadi di dunia dan akhirat (muflihun). ${ }^{1}$

Pendidikan merupakan kebutuhan penting bagi setiap negara, pemerintah secara umum dan sekolah secara khususnya. Terlebih lagi pendidikan agama, karena dari orang tualah anak-anak mula-mula menerima pendidikan. Bentuk pertama dari pendidikan terdapat dalam kehidupan keluarga. Pendidikan yang ditekankan tidak lain adalah pendidikan dengan konsep Islami yang menjadikan masalah penghambaan kepada Allah SWT, dan ketaatan kepada-Nya menjadi poros segala kehidupan. ${ }^{2}$

Dari kisah Luqman, dapat diambil pelajaran sebagai pedoman baik bagi orang tua maupun para pendidik dalam melaksanakan pendidikan. AlQur'an sebagi pedoman hidup umat Islam, memuat semua segi kehidupan dan berbagai kisah yang dapat dijadikan contoh pedoman dalam kehidupan.

Keywords: Pendidikan Islam, Luqman Al-Hakim
\end{abstract}

\section{A. Pendahuluan}

Menurut Suhaily, nama lengkapnya adalah Luqman bin 'Anaqa' bin

Sadun. Sedangkan Ibnu Ishaq menyatakan bahwa nama lengkapnya adalah Luqman bin Ba'ura' Najur bin Tarah. Tarah ini yang dimaksudkan adalah Azar, bapak Nabi Ibrahim A. S. Sebagaimana hal ini dicantumkan dalam Tafsir Al-Qurthubiy, Al-Jami'li Ahkam Al-Qur'an. Beliau adalah seorang hakim. Pendapat lain menyatakan bahwa beliau adalah seorang pengembala

${ }^{1}$ A. Syafi'I Ma'arif, Pendidikan Islam di Indonesia, Antara Cita dan Fakta, (Yogyakarta: Tiara Wacana, 1991), h. 41

${ }^{2}$ Muhammad Nasib, Ar-Rifa;I, Ringkasan Tafsir..., h. 789

Jurnal Ilmiah Al QALAM, Vol. 12, No. 1, Januari-Juni 2018 
kambing. Beliau bukan seorang nabi, karena tidak pernah memperoleh wahyu dari Allah, tetapi memperoleh hikmah.

Menurut satu pendapat, beliau hidup pada masa Nabi Dawud A. S, dan masih memiliki hubungan keluarga dengan nabi Ayyub, yakni anak bibinya (saudara sepupu). Meskipun demikian, pendapat keduanya menyatakan bahwa Luqman al-Hakim hidup di Negara Naubah. Satu pendapat lagi dikatakan bahwa beliau tinggal di Negara Habasyah.

Luqman al-Hakim adalah seorang hakim pada zaman Nabi Dawud, pendapat lainnya, belaiu adalah seorang pengembala kambing. Satu pendapat lagi menyatakan bahwa beliau adalah tukang kayu (najjar). Ada juga yang menyatakan bahwa beliau adalah seorang penjahit (khayyath). ${ }^{3}$

Al-Thabatabha'iy berpendapat bahwa luqman al-Hakim merupakan seorang yang kuat wara'nya, pendiam, cerdas pikirannya, menutup pandangan dari perbuatan maksiat, tidak menertawakan sesuatu, tidak pemarah, tidak memperolok-olokkan manusia lainnya, tidak gembira jika beliau menerima sesuatu dari persoalan duniawi. Beliau juga menikah dan memiliki banyak anak, dan tidak terlalu sedih jika ada diantara anaknya wafat. $^{4}$

Menurut jumhur ulama, termasuk di dalamnya Imam Malik bin Annas, bahwa Luqman adalah seorang laki-laki yang shalih dan bijaksana yang tidak dinyatakan bahwa beliau memperoleh wahyu dan tidak juga kalam malaikat. Dan secara ringkas dinyatakan bahwa beliau diberikan oleh Allah hikmah. Hal ini juga dikuatkan dengan cara mengajarkan kepada anaknya sebagaimana dinyatakan dalam Al-Qur'an dengan ungkapan "Huwa ya'idhuhu", yang ini mengingatkan bahwa ini adalah pengajaran (ta' lim) dan bukan menyampaikan syari'at.

\footnotetext{
${ }^{3}$ Imam Zuhair Hafidz, Al-Qashash Al-Qur'aniy Bayna Al-Abai wa Al-Abnai, (Beirut: Dar Al-Qalam, 1990), h. 329

${ }^{4}$ Muhammad Husain Al-Thabathaba'iy, Al-Mizan fi Tafsir Al-Qur'an, (Beirut: Muassasat al-'Alamiy li al-Mathbu'at, t,t), h. 221
}

Jurnal Ilmiah Al QALAM, Vol. 12, No. 1, Januari-Juni 2018 
Sementara itu, Ikrimah dan Al-Sya'biy berpendapat bahwa Luqman adalah seorang nabi. Mereka berasalan bahwa lafadz hikmah menunjukkan kemutlakan atas seorang nabi yang hal ini dinyatakan seperti dalam ayat AlQur'an yang ditujukan kepada Nabi Daud A. S. Sebagaimana dalam Surah Shad ayat 20, yang artinya: "Dan Kami berikan kepadanya (Nabi Dawud) hikmah dan kebijaksanaan dalam menyelesaikan perselisihan."

Kata hikmah ini ditafsirkan dengan nubuwwah (kenabian). Hal ini juga dinyatakan dalam Surah Al-Baqarah ayat 269 yang artinya: "Allah menganugerahkan al-hikmah kepada siapa yang dikehendaki-Nya. Dan Barangsiapa yang dianugerahi hikmah, ia benar-benar telah dianugerahi karunia yang banyak."

Kata hikmah yang dimaksud disini adalah mengetahui hakekat sesuatu atas apa yang ada di dalamnya, dan ini merupakan tanda kenabian.

Memperhatikan keduanya pendapat diatas, maka menurut jumhur ulama, termasuk di dalamnya pendapat Ibnu Abbas dan ulama Madinah, menyatakan bahwa beliau adalah seorang yang memperoleh hikmah, tapi bukan seorang nabi. ${ }^{5}$

\section{B. Konsep Pendidikan Islam dalam surah Luqman}

Pembahasan mengenai pendidikan yang diberikan oleh Luqman kepada anaknya dinyatakan dalam surah Luqman ayat 13:

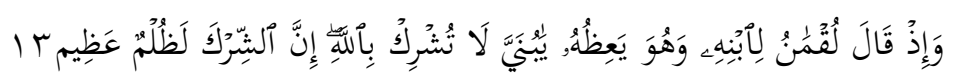

Artinya: "Dan (ingatlah) ketika Luqman berkata kepada anaknya, di waktu ia memberi pelajaran kepadanya".

Klausa ya 'izhuhu dalam klausa di atas merupakan fi'il mudhari' dari kata wa'azho. Kata wa'azho berasal dari huruf waw, 'ain, dan zho yang berarti memberikan peringatan dengan baik yang dapat menggugah dan

\footnotetext{
${ }^{5}$ Imam Zuhair hafidz, Al-Qashash al-Qur'aniy...., h. 328-330
}

Jurnal Ilmiah Al QALAM, Vol. 12, No. 1, Januari-Juni 2018 
melunakkan hati. ${ }^{6}$ Dengan kata lain, ya 'izhuhu bermakna upaya pemberian nasehat dan peringatan kepada orang lain untuk melakukan perbuatanperbuatan baik dengan ucapan yang dapat menyentuh dan menggerakkan hati.

Nasehat sebagai salah satu metode pendidikan, berarti peringatan yang mempunyai pengertian bersifat bimbingan dan pengarahan yang dapat membangkitkan emosi dan perasaan orang lain untuk mau melaksanakan perbuatan baik. ${ }^{7}$ Dengan nasehat bermkana menyajikan Bahasa tentang kebenaran dan kebajikan dengan maksud mengajak orang yang diberi nasehat untuk menjauhkan diri dari bahaya dan membimbingnya ke jalan yang bahagia dan berfaedah baginya. Suatu pertanda nasuhat yang baik adalah yang diberi nasehat, tidak sekedar mementingkan kemaslahatan bagi dirinya yang bersifat duniawi, tetapi ia juga mementingkan terhadap orang lain. Oleh karena itu, pendidik yang memberikan nasehat, hendaknya bersih dari perbuatan riya dan bersih dari anggapan orang bahwa perbuatannya itu memiliki maksud lain dari yang disampaikan. ${ }^{8}$ Dan ini berarti nasehat juga diperlukan dengan kecintaan. Dengan demikian, Luqman al-Hakim menerapkan metode pendidikan yang mampu menggugah perasaan dengan penuh kecintaan dan bijaksana yang dilakukan secara terus menerus. Metode yang menyentuh perasaan yang disesuaikan dengan perkembangan kejiwaan seseorang akan banyak memberikan pengaruh terhadap keberhasilan pendidikan.

Kemudian, Luqman al-Hakim juga menjelaskan kepada anaknya, yaitu larangan menyekutukan Allah. Dengan istilah lain, materi mendasar yang perlu ditanamkan kepada anak adalah tentang ketauhidan. Seorang h. 1098

${ }^{6}$ Ibn Faris Ibn Zakariya, Al-Maqayis fi al-Lughah, (Beirut: Dar al-Fikr, 1994),

${ }^{7}$ Muhammad Ibn Abi Bakr 'Abd al-Qadir al-Raziy, Mukhtar al-Shihah, (Beirut: Dar al-Kutub al-'Ilmiyyah, 1994), h. 647

${ }^{8}$ Abdurrahaman An-Nahlawi, Prinsip-prinsip dan Metode Pendidikan Islam, (Bandung: C. V. Diponegoro, 1992), h. 404

Jurnal Ilmiah Al QALAM, Vol. 12, No. 1, Januari-Juni 2018 
pendidik, dalam hal ini dinyatakan Luqman, perlu untuk memprioritaskan materi ketauhidan kepada yang terdidik dengan tidak menyekutukan Allah dengan apapun. Dan dinyatakan dalam ayat itu bahwa syirik adalah kezhaliman yang besar, karena dalam syirik itu menyamakan antara yang berhak untuk disembah dengan sesuatu yang tidak berhak disembah. Dengan demikian, syirik berarti menempatkan sesuatu yang berhak disembah terhadap sesuatu yang tidak berhak untuk disembah.

Dalam potongan ayat yang berbunyi: "Hai anakku, janganlah kamu menyekutukan Allah, karena menyekutukan Allah adalah kezhaliman yang besar". 9 Dapat difahami bahwa Luqman al-Hakim sebagai orang tua yang sedang memberi nasehat kepada anaknya agar tidak menyekutukan Allah. Hal ini mengindikasikan bahwa salah satu kewajiban orang tua terhadap anaknya adalah mengajarkan nilai-nilai tauhid dan mencegah atau menjauhkan anaknya dari kemusyrikan. ${ }^{10}$

Perintah untuk tidak berbuat syirik kepada Allah dikuatkan dengan ayat selanjutnya yang berbunyi: "Dan jika keduanya memaksamu untuk mempersekutukan dengan aku sesuatu yang tidak ada pengetahuanmu tentang itu, Maka janganlah kamu mengikuti keduanya, dan pergaulilah keduanya di dunia dengan baik.",II

Ayat ini menjelaskan bahwa jika orang tua memaksa anaknya untu mempersekutukan Allah, maka tida ada kewajiban bagi anak untuk mengikuti perintah tersebut. Meskipun demikian, hal ini tidak menghalangi untuk tidak berbuat baik. Seorang anak tetap harus menghormati orang tua dan tidak boleh memutuskan hubungan dalam kehidupan di dunia, walaupun orang tua termasuk musyrik. ${ }^{12}$ Berdasarkan pada ayat ini dapat ditegaskan bahwa melalui ayat-ayat Al-Qur'an, Allah menganjurkan kepada orang tua

\footnotetext{
${ }^{10}$ Imam Zuhair hafidz, Al-Qashash al-Qur'aniy...., h. 332

${ }^{12}$ Muhammad Ali al-Shabuniy, Shafwat al-Tafasir, Jilid III (Beirut: Dar al-
} Fikr, t.t), h. 492

Jurnal Ilmiah Al QALAM, Vol. 12, No. 1, Januari-Juni 2018 
untuk menanamkan ketauhidan kepada anaknya dan menjauhkan diri dari kemusyrikan.

Kata bunayya adalah bentuk tashghir (mengecilkan arti makna) dari kata Ibn. Penggunaan kata bunayya mengandung makna kasih sayang dan kecintaan Luqman al-Hakim kepada anaknya. Penggunaan kata bunayya berulang kali menunjukkan perlunya perhatian terhadap hal yang disampaikan. Konsep ini menunjukkan bahwa dalam proses pendidikan diperlukan rasa kasih sayang kepada orang yang diberi nasehat, sehingga ia dapat menerima nasehat yang diberikan dengan lapang dada. ${ }^{13}$

\section{Simpul-simpul Pendidikan Islam di dalam surah Luqman}

Pada ayat 12 dalam surah Luqman menjelaskan profil Luqman sebagai hamba Allah SWT yang diberi anugerah Al-Hikmah dari-Nya. Dengan Al-Hikmah itu ia mendidik anaknya menjadi hamba Allah yang senantiasa bersyukur. Langkah-langkah Luqman mendidik anaknya dalam upaya mencapai 'abdan syakuuraa dijelaskan dalam ayat 13-19 dengan rincian sebagai berikut:

1. Larangan berbuat syirik, yaitu menyekutukan Allah dengan segala sesuatu

2. Perintah berbuat baik kepada orang tua/keharusan berbuat baik kepada orang tua yang juga dibatasi oleh aturan-aturan Allah

3. Keimanan

4. Sholat dan 'Amar ma'ruf nahy munkar

5. Etika (Karakter)

Dari sisi redaksi, secara keseluruhan, di dalam bukunya Dr. H. Abd. Basir menjelaskan, ada 12 hal yang secara garis besar bisa dirangkum dalam tema-tema seperti berikut: Larangan berbuat syirik, berbuat baik kepada orang tua, mencari panutan hidup, mengajarkan keyakinan kepada hari

\footnotetext{
${ }^{13}$ Imam Zuhair hafidz, Al-Qashash al-Qur'aniy...., h. 332
}

Jurnal Ilmiah Al QALAM, Vol. 12, No. 1, Januari-Juni 2018 
kiamat, dan hari pembalasan atas perbuatan manusia, mengerjakan sholat, menegakkan prinsip amar ma'ruf nahy munkar, sabar menghadapi musibah, tidak sombong dan angkuh, serta berbicara dengan sopan santun. ${ }^{14}$ Sedangkan dari kutipan lain, simpul-simpul di dalam surah Luqman berisi 9 perintah, 3 larangan, dan 7 argumentasi. Sembilan perintah tersebut adalah: ${ }^{15}$

1. Berbuat baik kepada orang tua

2. Syukur kepada Allah dan orang tua

3. Berkomunikasi dengan baik kepada orang tua

4. Mengikuti pola hidup anbiya' dan shalihin

5. Menegakkan sholat

6. 'Amar ma'ruf

7. Nahy Munkar

8. Sederhana dalam kehidupan

9. Bersikap sopan dalam berkomunikasi

Adapun yang berbentuk larangan adalah:

1. Larangan syirik

2. Larangan bersikap sombong

3. Larangan berlebihan dalam kehidupan

Sedangkan ketujuh argument tersebut adalah:

1. Barangsiapa bersyukur, sungguh syukurnya itu untuk dirinya sendiri, dan barangsiapa kufur, sesungguhnya Allah Maha Kaya dan Maha terpuji.

2. Sesungguhnya syirik itu ialah kezaliman yang besar

3. Kepada-Nya manusia dikembalikan, untuk mempertanggung jawabkan apa yang telah diperbuatnya selama hidup di dunia

4. Sesungguhnya Allah Maha Mengetahui segala sesuatu

${ }^{14}$ Abd. Basir, Model Pendidikan Keluarga Qur'ani Studi Surah Ali Imran dan Luqman, (Banjarmasin, IAIN Antasari Press, 2015), h. 205

${ }^{15}$ http://husenblogs.blogspot.co.id/2011/11/materi-pendidikan-menuryttinjauan-al.html. Diaksess pada tanggal 23-Oktober-2017 pukul 03.13 PM

Jurnal Ilmiah Al QALAM, Vol. 12, No. 1, Januari-Juni 2018 
5. Sesungguhnya semua itu merupakan 'azmil umuur/ merupakan sesuatu yang telah diwajibkan

6. Sesungguhnya Allah tidak menyukai orang-orang yang sombong

7. Sesungguhnya sejelek-jeleknya suara adalah suara keledai.

Berangkat dari beberapa rincian diatas, simpul-simpul pendidikan yang terdapat di dalam surah Luqman kepada anak-anaknya dapat dikategorikan sebagai berikut:

\section{Pendidikan Aqidah}

Pendidikan aqidah adalah pendidikan yang berusaha mengenalkan, menanamkan serta mengantarkan anak akan nilai-nilai kepercayaan terhadap rukun-rukun iman dan lain sejenisnya. Dari nasehat-nasehat Luqman terhadap anaknya, termasuk dalam kategori pendidikan aqidah terdapat pada ayat 12, 13, dan 16 dari surah Luqman yaitu: larangan menyekutukan Allah dan meyakini adanya tempat kembali.

\section{a. Larangan Menyekutukan Allah}

Penanaman rasa keimanan yang murni sejak anak mulai diusia tingkat Taman Kanak-Kanak dan Sekolah Dasar sangatlah penting, sebab naluri anak-anak pada usia ini telah mampu menerima pendidikan keimanan.

Luqman al-Hakim sendiri pun memprioritaskan pendidikan tauhid kepada anaknya. Terbukti pendidikan tauhid telah mendapatkan tempat pertama dari wasiatnya dalam surah Luqman, yakni pada ayat ke-12 dan ke-13. Setelah pada ayat ke-12 diperintahkan bersyukur kepada Allah, yakni Dzat yang wajib ada, maka menurut ayat ke-13 Luqman berkata, "Hai anakku, janganlah kamu mempersekutukan Allah, sesungguhnya mempersekutukan Allah adalah benar-benar kezaliman yang besar." Syirik dinamakan perbuatan yang zalim, karena perbuatan syirik itu 
berarti meletakkan sesuatu bukan pada tempatnya, maka ia termasuk dalam kategori dosa besar. Perbuatan tersebut juga berarti menyamakan kedudukan Tuhan dengan makhlukNya. ${ }^{16}$ Walaupun pada hakikatnya keimanan atau kekufuran itu tidak mempengaruhi kebesaran-Nya sebagai Raja dari segala raja, akan tetapi demi kebahagiaan makhlukmakhluk-Nya, Dia pun memerintahakan agar makhlukmakhluk-Nya supaya beriman kepada-Nya. Inilah salah satu sifat Rahman dan Rahim Allah SWT, sebagaimana tertuang dalam firman-Nya:

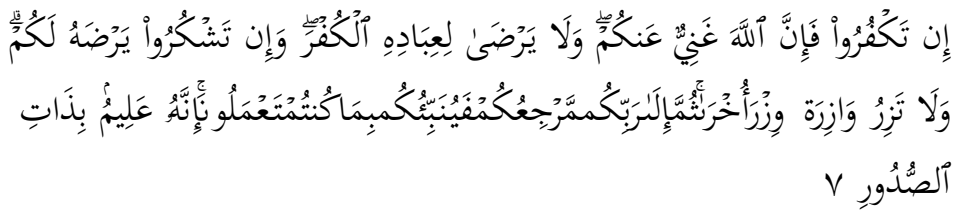

Artinya : Jika kamu kafir maka sesungguhnya Allah tidak memerlukan (iman)mu dan Dia tidak meridhai kekafiran bagi hamba-Nya; dan jika kamu bersyukur, niscaya Dia meridhai bagimu kesyukuranmu itu... ${ }^{17}$

Bila direnungkan lebih mendalam ada baiknya setiap individu belajar bersyukur atas berbagai nikmat yang diperolehnya, karena dengan bersyukur diharapkan mereka bisa meminimalisir bahkan bisa terhindar dari perbuatan syirik. Hal ini diperjelas oleh Imam Qurthubi dalam tafsirnya (Tafsir al-Qurthuby) bahwa hakikat bersyukur adalah menaati segala perintah dan menjauhi segala larangan-Nya. ${ }^{18}$ Dengan demikian, andaikata manusia mampu mensyukuri nikmat dengan sungguh-sungguh secara

\footnotetext{
${ }^{16}$ Ahmad Musthafa al-Maraghi, Tafsir al-Maraghi, terj. Bahrun Abu Bakar, dkk, (Semarang: Karya Toha Putra, 1992), h. 153

${ }^{17}$ QS. Al-Zumar, ayat: 7

${ }^{18}$ Qurthubi, Tafsir al-Qurthuby, 1992, h. 301
}

Jurnal Ilmiah Al QALAM, Vol. 12, No. 1, Januari-Juni 2018 
otomatis mereka tidak akan terperangkap dari perbuatan syirik.

Hal ini pun terlihat pada ayat ke-13, huruf 'ataf wawu pada awal ayat wa-idzqaala luqmaanu...laa tusyrik billaah itu ma'thuf-nya kembali pada ayat anisykur lillaah. Ini mengandung pemahaman bahwa sesungguhnya perbuatan syirik itu tidak akan dilakukan oleh orang-orang yang pandai bersyukur. Apalagi dengan adanya seruan Allah SWT yang mencegah segala bentuk tindakan syirik, maka sebagai makhluk yang berakal sudah semestinya ia tidak melakukan tindakan tersebut.

Dari penjelasan di atas, jelaslah syirik merupakan perbuatan keji dan munkar. Sehingga diharapkan para orang tua mampu memberikan pengarahan dan bimbingan sejak dini. Sebagaimana Luqman al-Hakim mengajarkan kepada anak-anaknya agar tidak terjerumus dalam perbuatan syirik.

\section{b. Meyakini adanya Tempat Kembali}

Penanaman keyakinan adanya balasan di akhirat (tempat kembali) merupakan suatu kepercayaan yang harus ditanamkan sejak anak masih kecil. Sehingga setiap aktivitas yang dilakukan anak terkontrol oleh norma-norma Islam. Disinyalir pengawasan alat negara ataupun pengawasan manusia lainnya tidak mampu mencegah perilaku yang menyimpang. Oleh karena itu, penanaman keimanan terhadap adanya pengawasan dari Yang Maha Melihat kepada anak sangat dibutuhkan, agar luruslah jalan anak menuju yang diridhai-Nya.

Dalam Tafsir al-Qur'an li al-Qur'an dijelaskan bahwa kata ilayya 'l-masiir pada ayat ke-14 diatas, mengandung isyarat sesungguhnya Allah SWT adalah Tuhan yang 
mengetahui segala urusan manusia. Hubungan antara anak dan kedua orang tuanya adalah sebatas perantara zahairiyyah wujudnya seorang anak di dunia, sedangkan mengenai urusan aqidah mereka tidak berhak menyesatkan anakanaknya. Oleh karena itu sebagai seorang anak hendaknya senantiasa berbuat baik kepada orang tua, sekaligus sebagai ungkapan terima kasih kepada keduanya.

Di sisi lain, ada yang menafsirkan kata ilayya ' $l$ masiir sebagai bentuk penegasan seruan taat kepada-Nya dan kepada kedua orang tua. Segala kebaikan dan keburukan yang dilakukan manusia baik kepada Allah SWT maupun kepada kedua orang tuanya akan dibalas di hari pembalasan tergantung amal yang diperbuat. ${ }^{19}$

Menurut Zakiah Darajat dengan adanya kesadaran akan pengawasan Allah yang tumbuh dan berkembang dalam pribadi anak, maka akan masuklah unsur pengendali terkuat di dalam kepribadian anak. Dengan demikian, kesadaran yang tinggi atas pengawasan-Nya akan berdampak positif terhadap jiwa psikologis anak dalam menjalani samudera kehidupan dikemudian hari terutama dalam menentukan sesuatu yang hak dan yang bathil. ${ }^{20}$

Mengingat begitu pentingnya penanaman keyakinan terhadap adanya pertanggung jawaban di hari akhir, maka diharapkan sebagai orang tua yang sadar akan tanggung jawabnya harus memberikan pengarahan dan bimbingan sebagaimana Luqman al-Hakim mendidik anak-anaknya. Perlu diingat bahwa penanaman keyakinan adanya hari

\section{7}

${ }^{19}$ Wahbah Zuhaili, Tafsir Al-Munir, Juz XXI, (Beirut: Darul Fikri, 1991), h.

${ }^{20}$ Zakiah Darajat, Ilmu Jiwa Agama, (Jakarta: Bulan Bintang, 1970), h. 63

Jurnal Ilmiah Al QALAM, Vol. 12, No. 1, Januari-Juni 2018 
pembalasan pada pribadi anak akan dapat bermanfaat sebagai salah satu upaya pengendalian terhadap diri pribadi seorang anak.

\section{Pendidikan Syari'ah}

Pendidikan syariah adalah pendidikan yang berusaha mengenalkan, menanamkan serta menghayatkan anak terhadap nilainilai peraturan Allah SWT tentang tata cara pengaturan perilaku hidup manusia, baik yang berhubungan secara vertikal dengan Allah SWT yang disebut ibadah, maupun berhubungan secara horizontal dengan makhluk-Nya, yang disebut hubungan muamalah. Dalam ibadah, bentuk peribadatan yang bersifat khusus pelaksanaannya telah dicontohkan oleh Nabi Muhammad SAW, seperti sholat, puasa dan zakat. Oleh karena itu, kita harus mengikuti apa yang dicontohkan Nabi. ${ }^{21}$

Syari'ah, yakni satu sistem norma Ilahi yang mengatur hubungan manusia dengan Tuhan, hubungan manusia dengan manusia, dan hubungan manusia dengan alam. Kaidah syari'ah ini terbagi menjadi dua: Pertama, ibadah, seperti sholat, thaharah, zakat, puasa, dan haji. Kedua, mu'amalah yakni tata aturan Ilahi yang mengatur hubungan manusia dengan manusia, dan hubungan manusia dengan alam dan harta benda. Aspek syari'ah ini termaktub pada ayat 14, 15, 17. Kategori yang termasuk di dalam Pendidikan Syari'ah adalah: Perintah mendirikan sholat, dan Perintah 'amar ma'ruf nahy munkar.

\section{a. Perintah Mendirikan Sholat}

Sholat adalah salah satu bentuk sarana ritual yang menandakan ketundukan seorang hamba kepada Tuhannya. Sholat juga bisa diartikan sebagi bentuk konkret manusia

\footnotetext{
${ }^{21}$ Ishak Abdullah, dkk. Moral dan Kognisi Islam, (Bandung: Alfabeta, 1993), h. 103
}

Jurnal Ilmiah Al QALAM, Vol. 12, No. 1, Januari-Juni 2018 
mensyukuri segala nikmat-Nya. Dalam hal ini, Luqman alHakim sebagai pribadi yang bertanggung jawab memerintahkan kepada anak-anaknya untuk mendirikan sholat. Perintah ini secara redaksional Nampak sangat jelas betapa Luqman mendidik anak-anaknya dengan menggunakan metode yang sangat humanis, yaitu model bertahap (tadrij). Mulai dari larangan berbuat syirik, menanamkan keyakinan adanya tempat kembali sebagai balasan atas berbagai amal manusia, dan perintah mendirikan shalat lima waktu. Sebagaimana Nabi Muhammad memberi tuntunan dalam haditsnya, Perintahkanlah anak-anakmu sholat ketika berumur tujuh tahun, dan pukullah mereka karena meninggalkan sholat jika telah berumur sepuluh tahun, dan pisahkan anak lakilaki dari anak perempuan dalam tempat tidur mereka." (HR. Abu Dawud, al-Turmudzi dan al-Hakim). ${ }^{22}$

Menurut Mushtafa al-Maraghi dalam kitab tafsirnya yang berjudul Tafsir al-Maraghi dijelaskan, perintah mendirikan sholat yang terdapat dalam surah Luqman ayat ke-17 mempunyai arti bahwa perintah untuk menjalankan sholat dengan sempurna dengan cara yang diridhoi-Nya. Karena di dalam sholat itu terkandung ridha Tuhan, sebab orang yang mengerjakannya berarti menghadap dan tunduk kepada-Nya. Dan di dalam sholat terkandung pula hikmah lainnya, yaitu dapat mencegah orang yang bersangkutan dari perbuatan keji dan mungkar. Maka apabila seseorang menunaikan hal itu dengan sempurna, niscaya bersihlah

\footnotetext{
${ }^{22}$ Hasan Langgulung, Beberapa Pemikiran Pendidikan Islam, (Bandung: alMa'arif, 1989), h. 373
}

Jurnal Ilmiah Al QALAM, Vol. 12, No. 1, Januari-Juni 2018 
jiwanya dan berserah diri kepada-Nya, baik dalam keadaan suka maupun duka. ${ }^{23}$

Dengan demikian, merupakan suatu keniscayaan apabila para orang tua maupun para pendidik mulai mengajarkan nilai-nilai dari pelaksanaan sholat kepada anakanaknya. Baik mengajarkan nilai-nilai yang terkandung dalam bacaan sholat, maupun nilai-nilai dari gerakannya. Minimal memberi pemahaman bahwa sholat bukanlah sekedar ritualitas tanpa makna, melainkan ritualitas bermakna yang dapat mengantarkan anak-anak menjadi pribadi yang sukses, baik di dunia maupun akhirat. Terlebih apabila penanaman dan pendidikan yang demikian ini diajarkan para orang tua pada saat anak-anak masih berumur 0-12 tahun, niscaya mereka akan senantiasa mengingat, mengamalkan, dan menjadikan batu pijakan nasihatnasihatnya tersebut dalam menjalani kehidupan sehari-hari. ${ }^{24}$

\section{b. Perintah Amar Ma'ruf Nahy Munkar}

Setelah menyuruh anak-anaknya untuk mendirikan sholat, Luqman al-Hakim pun pada ayat ke-17 melanjutkan nasihatnya, agar anak-anaknya supaya berbuat kebaikan dan mencegah kemungkaran, Al-Zuhaili menafsirkan kalimat wa'mur bi'l-ma'ruuf pada ayat ke-17 ini sebagai ajakan Luqman al-Hakim kepada dirinya sendiri maupun orang lain (anak-anaknya) untuk berbuat kebajikan, seperti budi pekerti yang baik, melakukan pekerjaan yang mulia, membersihkan jiwa dari keburukan. Sedangkan kalimat wanhaa 'an almunkar sebagai ajaknnya untuk mencegah kemaksiatan,

\footnotetext{
${ }^{23}$ Ahmad Musthafa al-Maraghi, Tafsir al-Maraghi...., h. 158

${ }^{24}$ Sumadi Suryabrata, Psikologi Pendidikan, (Jakarta: Rajawali Press, 1995), h.

Jurnal Ilmiah Al QALAM, Vol. 12, No. 1, Januari-Juni 2018 
kejelekkan dan kemungkaran baik kepada dirinya sendiri maupun kepada orang lain yang bisa menyebabkan kemurkaan Allah SWT. ${ }^{25}$

Lain halnya dengan al-Zuhaili, al-Maraghi menafsirkan kalimat wa'mur bi 'l-ma'ruf dalam surah Luqman ayat ke-17 ini sebagai seruan Luqman al-Hakim agar orang lain (anak-anaknya) supaya mau memberishkan dirinya sesuai dengan kemampuannya. Maksudnya supaya jiwanya menjadi suci dan demi untuk mencapai keuntungan. Sedangkan kalimat wanhaa 'an al-munkar ditafsirkan sebagai seruan agar manusia mau mencegah perbuatan durhaka kepada Allah SWT, dan dari mengerjakan laranganlarangan-Nya yang membinasakan pelakunya serta menjerumuskannya ke dalam azab neraka yang apinya menyala-nyala, yaitu neraka Jahannam dan seburuk-buruk tempat kembali adalah neraka Jahannam. ${ }^{26}$

Walaupun sepintas, kedua mufassir di atas, berbeda pendapat dalam memberi penafsiran tentang makna amar ma'ruf nahy munkar. Namun pada prinsipnya, keduanya sependapat bahwa perintah kebajikan dan mencegah berbagai kejelekan merupakan perintah Luqman al-Hakim kepada anak-anaknya pada khususnya dan umat manusia pada umumnya. Dengan demikian, pada orang tua maupun para pendidik hendaknya mau mengikuti jejak Luqman alHakim yang tidak pernah bosan menyerukan kebaikan dan mencegah segala bentuk kemungkaran dimana pun ia berada. Tentunya sesuai dengan kemampuan dan kapasitasnya masing-masing.

\footnotetext{
${ }^{25}$ Wahbah Zuhaili, Tafsir Al-Munir,..., h. 150

${ }^{26}$ Ahmad Musthafa al-Maraghi, Tafsir al-Maraghi..., h. 159
}

Jurnal Ilmiah Al QALAM, Vol. 12, No. 1, Januari-Juni 2018 


\section{Pendidikan Akhlak}

Pendidikan akhlak adalah pendidikan yang berusaha mengenalkan, menanamkan serta menghayatkan anak akan adanya sistem nilai yang mengatur pola, sikap dan tindakan manusia diatas bumi. Pola sikap dan tindakan yang dimaksud mencakup pola-pola hubungan dengan Allah SWT, sesama manusia (termasuk dengan dirinya sendiri) dan dengan alam sekitar. ${ }^{27}$ Alih kata, pendidikan akhlak adalah suatu pendidikan yang berusaha mengimplementasikan nilai keimanan seseorang dalam bentuk prilaku. ${ }^{28}$ Sebab pendidikan akhlak adalah bagian yang tidak dapat dipisahkan dari pendidikan agama. Sehingga sesuatu, dianggap baik atau buruk oleh seseorang manakala berdasarkan pada agama. ${ }^{29}$

Adapun nilai pendidikan akhlak yang terdapat dalam surah Luqman pada ayat ke-12-19 adalah mensyukuri nikmat Allah SWT. Atas segala nikmat dan karunia Allah, kita harus bersyukur kepadaNya. Nikmat Allah meliputi seluruh hidup, sehingga tidak mungkin bagi kita untuk menghitungnya, mulai dari nikmat yang berhubungan dengan jasmani, rohani, materi, non materi dengan berbagai ragam, sebagaimana Allah berfirman dalam Al-Qur'an yang berbunyi:

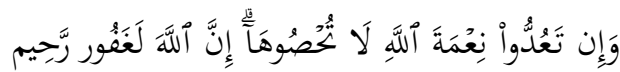

Artinya: Dan jika kamu menghitung-hitung nikmat Allah, niscaya kamu tak dapat menentukan jumlahnya. Sesungguhnya Allah benar-benar Maha Pengampun lagi Maha Penyayang ${ }^{30}$

Nikmat adalah kesenangan, pemberian atau karunia yang diberikan-Nya kepada manusia. Menurut Imam al-Ghazali, nikmat

\footnotetext{
${ }^{27}$ Ishak Abdullah, dkk. Moral dan Kognisi Islam, ..., h. 103

${ }^{28}$ Zakiah Darajat, Ilmu Jiwa Agama,...., h. 58

${ }^{29}$ Hasan Langgulung, Beberapa Pemikiran Pendidikan Islam,...., h. 373

${ }^{30}$ Qur'an Surah al-Nahl, ayat: 18
}

Jurnal Ilmiah Al QALAM, Vol. 12, No. 1, Januari-Juni 2018 
berarti setiap kebaikan yang dapat dirasakan kelezatannya dalam kesenangan hidup, tetapi nikmat yang sejati adalah kesenangan hidup di akhirat. Sedangkan syukur menurut Hamka adalah orang yang mampu mempertinggi dirinya sendiri dengan cara mengenang dan menghargai jasa orang lain. Orang yang paling berjasa terhadap diri kita adalah kedua orang tua. Sehingga Tuhan pun memerintahkan setiap manusia agar bersyukur kepada keduanya, dan pada prinsipnya yang maha berjasa adalah Allah SWT. ${ }^{31}$

Jadi, secara etimologis, akhlak adalah perbuatan yang mempunyai sangkut paut dengan khaliq (Pencipta). Akhlak ini mencakup akhlak manusia terhadap khaliqnya, dan akhlak manusia terhadap makhluknya. Aspek ini terdapat pada ayat 14,15,18, dan 19. Baik ibadah, mu'amalah, dan akhlak pada hakikatnya bertitik tolak dari aqidah.

\section{Analisis}

Adapun analisis penulis dalam simpul-simpul pendidikan Luqman al-Hakim ketika mendidik anaknya adalah menggunakan Nasehat, Targhiib wa tarhiib, dialog (hiwaar), Keteladanan, Pembiasaan, dan Perumpamaan.

\section{Metode Nasihat (Mau'izzah)}

Mau'izah adalah nasihat bijaksana yang dapat diterima oleh pikiran dan perasaan orang yang menerimanya. Mau'izah sering siartikan sebagai nasihat yang disajikan dengan cara yang dapat menyentuh kalbu.

Nasihat adalah kata yang dipergunakan untuk mengungkapkan keinginan yang baik untuk orang yang dinasehati. Atau nasihat suatu kata yang mengandung arti bahwa orang yang

\footnotetext{
${ }^{31}$ Hamka, Tafsir al-Azhar, Juz XXI, (Surabaya: Yayasan Latimojong 1991), h.

Jurnal Ilmiah Al QALAM, Vol. 12, No. 1, Januari-Juni 2018 
menasehati menginginkan sekaligus melakukan berbagai macam kebaikan untuk orang yang dinasehati ${ }^{32}$

Nasihat Luqman al-Hakim merupakan metode Pendidikan yang mampu menggugah perasaan dan hati, serta dilakukan secara terus menerus. Secara eksplisit, metode yang diterapkan Luqman alHakim sesuai dengan perkembangan kejiwaan peserta didik. Karena nasihat memberikan implikasi psikologis terhadap perkembangan pendidikan anak. Nasihat selalu dibutuhkan oleh jiwa karena memberikan ketenangan hati, apalagi jika nasihat itu timbul dari hati yang ikhlas dan jiwa suci. ${ }^{33}$

Nasihat dalam Islam memiliki tempat yang penting karena dapat menyebabkan terciptanya kesejahteraan, ketentraman, dan keberkahan masyarakat. Memberikan nasihat memiliki peran yang penting dalam memantapkan persaudaraan di antara umat Islam.Terlebih, jika nasihat itu diberikan hanya karena Allah SWT dan muncul karena kasih sayang dan memberikan gambaran bahwa pemberi nasehat menaruh perhatian besar supaya saudaranya mendapat kebaikan.

\section{Targhiib wa tarhiib}

Secara psikologis dalam diri manusia ada potensi kecenderungan berbuat kebaikan dan keburukan. Oleh karena itu Pendidikan Islam berupaya mengembangkan manusia dalam berbagai metode guna melakukan kebaikan yang dilandasi dengan keimanan. Namun sebaliknya Pendidikan Islam berupaya semaksimal mungkin menjauhkan manusia dari perbuatan buruk dengan berbagai aspeknya. Jadi tabiat baik harus dikembangkan

${ }^{32}$ Abd al-Rahman 'Umdirah, Manhaj Alqur'an fi al-Tarbiyah al-Rijaal, diterjemahkan Abd Hadi Basultanah dengan Judul, Metode AlQuran dalam Pendidikan, (Surabaya: Mutiara Ilmu, t.t.), h. 210

${ }^{33}$ Abd. Basir, Model Pendidikan Keluarga Qur'ani Studi Surah Ali Imran dan Luqman, (Banjarmasin, IAIN Antasari Press, 2015), h. 177-178

Jurnal Ilmiah Al QALAM, Vol. 12, No. 1, Januari-Juni 2018 
dengan cara memberikan imbalan, penguatan dan dorongan. Sementara tabiat buruk perlu dicegah dan dibatasi ruang geraknya.

Konteksnya dengan metode Pendidikan Luqman al-Hakim ketika mendidik anaknya, Luqman disamping menggunakan metode nasihat juga menerapkan metode targhiib dan tarhiib. Hal ini bisa dibuktikan dari ayat-ayat yang diungkapkan Allah SWT, tentang Luqman. Seperti ketika Luqman meberikan nasihat kepada anaknya dengan mengatakan "Janganlah kamu berbuat syirik karena syirik itu suatu kezaliman yang besar". 34 Begitu juga ketika Luqman mengatakan, "Hai anakku, sesungguhnya jika sesuatu perbuatan seberat zarrah yang berada dalam batu atau di langit atau di bumi, niscaya Allah akan membalasnya.",35

Metode targhiib dan tarhiib sebenarnya sangat berguna dalam rangka menanamkan nilai-nilai keimanan kepada anak. Apabila keimanan menjadi sebuah nilai- dalam kehidupan anak, maka pada akhirnya berimplikasi kepada amal saleh dan akhlak mulia.

\section{Dialog (Hiwaar)}

Metode dialog dikenal dalam bahasa Arab dengan istilah alhiwaar, yaitu percakapan timbal balik atau komunikasi dua arah antara dua pihak atau lebih mengenai suatu topik tertentu dan dengan sengaja diarahkan kepada suatu tujuan yang dikehendaki oleh pendidik. $^{36}$

Komunikasi efekti antara Luqman dan anaknya, mengisyaratkan bahwa seorang pendidik agar tidak menempatkan peserta didik sebagai objek pendidikan saja. Kalau hanya sekedar objek Pendidikan, maka komunikasi Pendidikan hanya berjalan satu

${ }^{34}$ Lihat Q.S. Luqman, ayat: 13

${ }^{35}$ Lihat Q.S. Luqman, ayat: 16

${ }^{36}$ Abd al-Rahman al-Nakhlawy, dalam bukunya Abd. Basir, Model Pendidikan Keluarga Qur'ani Studi Surah Ali Imran dan Luqman, ..., h. 180

Jurnal Ilmiah Al QALAM, Vol. 12, No. 1, Januari-Juni 2018 
arah saja. Seorang Pendidik mesti memposisikan anak sebagai subjek pendidikan sehingga pendidikan berjalan dua arah. Dengan demikian potensi pikir anak dapat dikembangkan untuk lebih mendekatkan anak kepada Allah SWT.

\section{Keteladanan}

Keteladanan dalam pendidikan merupakan metode yang sangat efektif untuk membentuk kepribadian peserta didik, terutama pada aspek moral, spiritual maupun sosial. Pentingnya metode keteladanan ini, bahwa peserta didik lebih banyak mengambil pelajaran dengan meniru perilaku gurunya. Cara ini menurutnya jauh lebih berpengaruh kepada peserta didik daripada melalui metode nasehat dan petuah lisan.

Keteladanan dalam Pendidikan menempatkan orang tua dan pendidik sebagi contoh atau model terbaik dalam pandangan peserta didik yang akan ditirunya dalam segala perilakunya, sopan santunnya, dan semua ucapannya. Bahkan disadari atau tidak, figure pendidik tercetak atau tergambar dalam jiwa peserta didik. Sebab secara psikologis, peserta didik memang senang meniru, tidak saja sifat-sifat yang baik, tetapi juga sifat-sifat tercela sekalipun. Karena seorang bapak dalam pandangan anaknya (pada tahun-tahun pertama usianya) sebagai orang yang paling sempurna dan paling mulia, karenanya ia akan meniru dan meneladani bapaknya. ${ }^{37}$

Dengan demikian, seorang pendidik harus bisa menjadi teladan dalam semua aspek kehidupan, baik perkataan dan perbuatannya bagi peserta didik. Pada hakikatnya, akhlak yang baik dan mulia merupakan dakwah praktis bagi anak didiknya. Karena itu, setiap gerak-gerik seorang pendidik harus mengandung dasar-

${ }^{37}$ Adnan Hasan Shaleh Baharits, Masuuliyyah al-Abb al-Muslim fi Tarbiyah alWalad fi Marhalah al-Thufuulah, (Jeddah: Dar al-Matba' li al-Nasyr wa al-Tauzi, 2005), cet. Ke-10, h. 61

Jurnal Ilmiah Al QALAM, Vol. 12, No. 1, Januari-Juni 2018 
dasar dan nilai-nilai kebaikan serta mengajak peserta didik untuk turut melaksanakan akhlak yang baik sebagaimana akhlak yang dicontohkan oleh Rasulullah SAW.

\section{Pembiasaan}

Pembiasaan menurut Muhammad Quthb merupakan metode yang sangat istimewa dalam kehidupan manusia, karena melalui pembiasaan inilah terjadi perubahan seluruh sifat dan menjadi kebiasaan yang terpuji pada diri seseorang. ${ }^{38}$

Jika dicermati, Luqman al-Hakim dalam mendidik anaknya menerapkan metode pembiasaan. Metode ini diterapkan dengan memberikan penanaman nilai secara berulang-ulang menyangkut semua materi Pendidikan. Indikator penerapan metode ini selaras dengan metode nasihat dan keteladanan yang telah ia lakukan. Nasihat dan keteladanan diberikan secara terus menerus kepada anaknya, proses kuntinuitas ini menunjukkan adanya pembiasaan.

\section{Perumpamaan (Amstal)}

Luqman al-Hakim menyampaikan materi Pendidikan kepada anaknya, terutama berkaitan dengan tauhid dan akhlak atau perilaku seseorang di antaranya adalah dengan metode yang logis dan rasional. Cara seperti ini memang tepat sekali untuk memperkuat keyakinan anaknya pada kebenaran ajaran yang disampaikan.

Metode perumpamaan yang dilakukan oleh Luqman alHakim diantaranya ketika menyampaikan materi tentang etika sosial, yaitu adab dalam bertutur kata, sebagaimana terdapat pada ayat ke19. Perumpamaan yang dimaksud adalah keledai dengan sifat yang melekat dalam dirinya yang digunakan untuk mengumpamakan orang yang bersuara keras. Sedangkan tujuan yang tersirat di

\footnotetext{
${ }^{38}$ Muhammad Quthb,dalam bukunya Abd. Basir, Model Pendidikan Keluarga Qur'ani Studi Surah Ali Imran dan Luqman, ..., h. 184
}

Jurnal Ilmiah Al QALAM, Vol. 12, No. 1, Januari-Juni 2018 
dalamnya adalah agar peserta didik tidak berbuat sombong, tetapi dapat berkata dan berprilaku lemah lembut dan sopan. ${ }^{39}$

Uraian di atas dapat disimpulkan, bahwa perumpamaan merupakan salah satu metode penting Pendidikan untuk mempengaruhi perilaku manusia dan menumbuhkan nilai-nilai keislaman dalam arti setiap muslim jika digunakan secara bijaksana dan dalam kondisi yang tepat.

\section{E. Kesimpulan}

Berdasarkan paparan diatas, ada dua hal yang dapat di jadikan konklusi, Pertama, simpul-simpul pendidikan Islam di dalam surah luqman pada dasarnya meliputi tiga pendidikan fundamental, yaitu: pendidikan aqidah pada ayat 12,13 , dan 16 , pendidikan syari'ah pada ayat 14,15 , dan 17, dan pendidikan akhlak pada ayat 14, 15, 18, dan 19.

Kedua, Implikasi simpul-simpul pendidikan Islam yang terkandung dalam surah Luqman tersebut, menjadikan pembentukan kepribadian yang islami sebagai salah satu pilihan guna membentengi anak sedini mungkin dari pengaruh lingkungan yang negatif. Pembentukan kepribadian anak pada prinsipnya merupakan proses yang berkelanjutan. Dan secara keseluruhan, simpul-simpul di dalam surah Luqman berisi 9 perintah, 3 larangan, dan 7 argumentasi.

${ }^{39}$ Abd. Basir, Model Pendidikan Keluarga Qur'ani Studi Surah Ali Imran dan Luqman,..., h. 185

Jurnal Ilmiah Al QALAM, Vol. 12, No. 1, Januari-Juni 2018 


\section{Daftar Pustaka}

Abdullah, Ishak. dkk. 1993. Moral dan Kognisi Islam. Bandung: Alfabeta

Al-Maraghi, Ahmad Musthafa. 1992. Tafsir al-Maraghi, terj. Bahrun Abu Bakar, dkk. Semarang: Karya Toha Putra

Al-Qur'anul Karim, terj. Departemen Agama.

Al-Shabuniy, Muhammad Ali. t.t. Shafwat al-Tafasir. Jilid III. Beirut: Dar alFikr

Al-Thabathaba'iy, Muhammad Husain. t.t. Al-Mizan fi Tafsir Al-Qur'an. Beirut: Muassasat al-'Alamiy li al-Mathbu'at

An-Nahlawi, Abdurrahaman. 1992. Prinsip-prinsip dan Metode Pendidikan Islam. Bandung: C. V. Diponegoro

Ar-Rifa'I, Muhammad Nasib. 1999. Ringkasan Tafsir Ibnu Katsir. Pentj Syihabuddin. Cet. I. Jakarta: Gema Insani Press

Basir, Abd. 2015. Model Pendidikan Keluarga Qur'ani Studi Surah Ali Imran dan Luqman. Banjarmasin: IAIN Antasari Banjarmasin.

Darajat, Zakiah. 1970. Ilmu Jiwa Agama. Jakarta: Bulan Bintang.

Hafidz, Imam Zuhair. 1990. Al-Qashash Al-Qur'aniy Bayna Al-Abai wa AlAbnai. Beirut: Dar Al-Qalam

Hamka. 1991. Tafsir al-Azhar, Juz XXI. Surabaya: Yayasan Latimojong

http://husenblogs.blogspot.co.id/2011/11/materi-pendidikan-menuryt-tinjauanal.html

Langgulung, Hasan. Beberapa Pemikiran Pendidikan Islam. Bandung: alMa'arif.

Ma'arif, A. Syafi'I. 1991. Pendidikan Islam di Indonesia, Antara Cita dan Fakta. Yogyakarta: Tiara Wacana.

Marimba, Ahamd D.1989. Pengantar Filsafat Pendidikan Islam. Bandung: AlMa'arif

Suryabrata, Sumadi. 1995. Psikologi Pendidikan. Jakarta: Rajawali Press

Umdirah, Abd al-Rahman. t.t. Manhaj Alqur'an fi al-Tarbiyah al-Rijaal, diterjemahkan Abd Hadi Basultanah dengan Judul, Metode AlQuran dalam Pendidikan, Surabaya: Mutiara Ilmu.

Zakariya, Ibn Faris. 1994. Al-Maqayis fi al-Lughah. Beirut: Dar al-Fikr

Zuhaili, Wahbah. 1991. Tafsir Al-Munir. Juz XXI. Beirut: Darul Fikri

Jurnal Ilmiah Al QALAM, Vol. 12, No. 1, Januari-Juni 2018 
Abdan Rahim:Pendidikan Islam Dalam Surah Luqman

Jurnal Ilmiah Al QALAM, Vol. 12, No. 1, Januari-Juni 2018 